\title{
Sport, the Military and Peacekeeping: History and Possibilities
}

\author{
Richard Giulianotti and Gary Armstrong \\ This is a copy of the Author's Original Text of an article whose final and definitive from, the \\ Version of Record, has been published in Third World Quarterly [copyright Taylor and Francis], \\ DOI: $10.1080 / 01436597.2011 .573935$
}

To Cite: Giulianotti, R. and Armstrong, G., (2010) Sport, the Military and Peacekeeping: History and Possibilities, Third World Quarterly, 32:3, 379-394.

\author{
Part of this research was financed through a grant from the Nuffield Foundation \\ Published Version Available At: \\ http://www.tandfonline.com/doi/abs/10.1080/01436597.2011.573935\#.U-t1-fldV8E
}

\begin{abstract}
This paper examines the role and contribution of peace-making to the wider sport, development and peace (SDP) sector. Particular attention is paid to a hitherto under-explored subject: the complex position of the military vis-a -vis sport and sport-related peacekeeping. Through an historical overview of the sport-military intersection, reference to fieldwork in Bosnia and Liberia, and a brief examination of the Conseil Internationale du Sport Militaire, some critical and cautious conclusions are put forth. We suggest that sport-based peacemaking interventions provide the military with a new kind of institutional function, and fresh ways of building positive social links to civilian populations. However, such engagement is only possible if full dialogical engagement between civilians and peacekeeping forces is established, in which the military adapt their practices to suit the local cultural context.
\end{abstract}

In recent years governments, UN agencies and nongovernmental organisations (NGOs) have become increasingly supportive of the notion that sport can be used as a tool in the pursuit of development and peace. By 2007 an estimated 400 recognised NGOs in the field of sport, development and peace (SDP) were in existence, and a further 10 NGOs per month were being created. ${ }^{1}$

This faith in sport as a tool of reconciliation has been driven in large part by powerful institutional forces. In November 2003 the UN General Assembly proclaimed 2005 as the International Year of Sport and Physical Education (IYSPE). A significant component of the IYSPE was to harness sport as an interventionist tool for peace building; the objective here was to 'promote collective work promoting sport and physical education-based opportunities for 
solidarity and cooperation in order to promote a culture of peace and social and gender equality and to advocate dialogue and harmony'. ${ }^{2}$ In developing this work, the UN has built substantial partnerships with transnational corporations, NGOs, national governments, sport federations and clubs, and other agencies and organisations. ${ }^{3}$

Much of this work has centred on using sport to achieve the UN's Millennium Development Goals (MDGs), which are key targets aimed at meeting fundamental human needs, such as eradicating extreme hunger and poverty, establishing universal primary education, cutting child mortality and HIV/AIDS infections, and promoting gender equality, all by 2015. Arguably a greater, institutionalised focus should be placed on peace building and conflict resolution, as such work serves to establish the essential social preconditions for the successful implementation of the MDGs and other development initiatives.

In this paper we examine the role and contribution of peace-making to the wider SDP sector. Our particular focus here is on a hitherto under-explored subject: the complex position of the military vis-a -vis sport and sport-related peacekeeping. The paper builds upon our previous research in relation to sport and peace, and more broadly in regard to sport and development, particularly in the global South. ${ }^{4}$

The discussion and analysis is substantially underpinned by our extensive, prior fieldwork in diverse locations, notably Liberia and Bosnia; supplementary fieldwork has also been undertaken in the Middle East, Nigeria and Sri Lanka. However, largely for reasons of brevity, we are unable to enter into a full discussion of this fieldwork. We should also note that most of our focus is on football, for the simple reason that this sport was by far the most commonly encountered one during our research, particularly in the Balkans and West Africa.

The paper is divided into four main parts. First, we examine the different historical phases of the sport-military intersection. Second, we provide specific case studies of the sport-military nexus in Bosnia and Liberia. Third, we consider the case of one sport military movement, the Conseil Internationale du Sport Militaire, and its potential contribution to sport-related peace-keeping activities. Fourth, we conclude in critical terms by setting out specific practical and policycentred ways in which the sport-military intersection may be positively developed within conflict and post-conflict situations and the broader context of the global South. 
In broad terms we argue that sport-based, peace-making interventions provide the military with a new kind of institutional function, and fresh ways of building positive social links to civilian populations. However, such engagement is only possible if full dialogical engagement between civilians and peacekeeping forces is established, in which the military adapt their practices to suit the local cultural context.

\section{Sport and the military: war and peace}

Any analysis of the sport-military intersection, with respect to peace building, must consider the historical context in which that relationship has been developed. In general terms it has to be recognised that sport has stood in an 'ambivalent' relationship with war and peace. ${ }^{5}$ Since antiquity the analogies and overlaps between sport and war have concentrated the minds of eminent scholars. In Plato's Republic Socrates and Glaucon, discussing the type of gymnastic training appropriate for the guardians of the city, compare the similarities and differences between an athlete and a soldier. ${ }^{6}$ Aristotle discussed courage in his Nicomachean Ethics and drew an analogy between war and competitive sport when stating, 'A courageous action in war is pleasant, it is concealed in the same way that the pleasure of honour and victory felt by a boxer endures to obtain that honour'. ${ }^{7}$ For Aristotle, in the absence of war, humans assure themselves of self-worth through their deeds on the sports field.

These historical insights from antiquity remind us that, in many ways, there is no essential connection between sport, peace and social harmony. In the 'play' that takes place on the sporting field per se, some analysts have discerned both real and mimetic forms of violent conflict. ${ }^{8}$ Moreover, both ancient and modern sports have featured transgressive and violent carnivalesque practices among participants and spectators, which are often underpinned by deeply antagonistic types of social solidarity. Consider, for example, the intense ethno-nationalist and ethno-religious rivalries that are sometimes displayed at sports fixtures involving the Balkan nations, or India and Pakistan, or China and Japan.' Within most nations 'derby' fixtures between football clubs from the same city or region feature routine expressions of hostility and opposition. Strong commonalities may also be identified in how heroes on the fields of sport and in the heat of battle are socially constructed and popularly represented. ${ }^{10}$ Moreover, sports have also been used as an important socio-cultural field for reproducing highly divisive or violent forms of social stratification and exclusion. South Africa under apartheid provides an extreme case study, although we may also point at the ways in which the lower classes, women and nonwhite communities have struggled to overcome their exclusion or oppressive treatment with 
regard to different forms of sport participation. Thus, despite ideological claims that the two must remain separate, sport and politics are forever entwined, such that political interests always mark sporting practices and organisations. This inseparability of sport and politics is, inevitably, demonstrated in the historical relationships between sport, the military and warfare. Such a nexus also ensures that we should consider the possibility that the use of sport as a peace-making tool may actually backfire, and may serve to extend rather than undermine social conflicts.

With these arguments in mind, we set out below a model of three broad historical phases to trace the military's relationship to modern sport. Our discussion is based on an earlier model, developed elsewhere, ${ }^{11}$ which traces the more generalised global diffusion of sport, notably in relation to the global South. We realise that these stages are not hermetically sealed; therefore trends and features that are apparent within the first and second stages may be identified within the third. However, these phases do help us to understand the different trends and possibilities that are apparent in the sport-military nexus at specific historical junctures.

\section{Sport-military-global society 1: colonialism and 'civilisation'}

This phase spans from around the late 18th to the mid-20th centuries. During this period sport was a key element within wider colonial projects, in the European (especially, British) colonisation of land, and the extermination and control of indigenous peoples across nonEuropean territories. In this way modern sport played key politico-ideological and socio-cultural roles in the construction of Empire.

In Britain the development of modern sports was closely tied to militarism, imperialism and the then hegemonic forms of masculinity, as demonstrated particularly through attempts to cultivate 'muscular Christian gentlemen'. ${ }^{12}$ The dominant ideologies of the time served to exclude women from sport, or to allow only supportive roles for the 'fairer sex'. Where the military were involved, such gender-based differences tended to be most rigidly held. Although apocryphal, the statement popularly attributed to Lord Wellington, that 'The Battle of Waterloo was won on the playing-fields of Eton', came to epitomise the dominant assumption in British imperial ideology, namely that sporting practices can contribute massively to masculine military pedagogy. This ideology reached its zenith before and during the First World War, when numerous works of literature deployed the similes of war-as-game and sportsman-as-soldier. For example, in EW Hornung's poem 'Lord's Leave 1915', the terrain of war becomes a cricket match in which: 
The public school boy faces the Hun demon bowler, his field gun trained upon the stumps pumping Krupp's shells from 'a concrete grandstand far beyond the boundary.' The stars blink down from the pavilion and the conditions are atrocious - 'no screen and too much mud for cricket lovers'; but there is no appealing against the light in this match. ${ }^{13}$

In the British army sport was inseparable from Christian beliefs. ${ }^{14}$ The school and sporting curricula encouraged notions of physical and mental courage, loyalty and esprit de corps, instilling senses of 'fair play' and the humility to bear defeat well—all underpinned by assumptions that war and sport were played out by men according to 'gentlemanly' rules. Such thinking had no doubt been apparent in 1863, when coincidentally both the Geneva Convention and the rules of association football were established.

Sport practices propagated British imperial sentiment and governance. The British Empire was in part an enormous sports complex, driven institutionally by the military and the church; ${ }^{15}$ thus, 'sport travelled the world with the bullet and the bible'. ${ }^{16}$ In turn, sport was one routine cultural and physical sphere for the development of an imperial governmentality of death which furnished fallen men with a 'code for dying in a dignified "British" manner. ${ }^{17}$ Overall, this first phase established the deep connections between sport and the war-making masculinities of the modern military. Sport provided pedagogies of soldiering for all forces at the sharp end of conflicts.

\section{Sport-military-global society 2: nationalism, ideology and armed conflict}

This phase spans the 1940s to the 1990s, during which time sport was inevitably caught up in highly contested colonial and postcolonial struggles, particularly in Africa and Latin America, and within the cold war context. ${ }^{18}$

During this period we find further markers of the correlation between sport, war and violent conflict, which are often heavily inflected by nationalism, para-militarism and ideological struggle. In more extreme instances, sport appeared as a catalyst for warfare. The so-called 'Soccer War' between Honduras and El Salvador in 1969 was sparked by rioting after a World Cup qualifying match between the two countries, which led to 100 hours of armed conflict and the death of an estimated 2000 people. ${ }^{19}$ Further instances of state-driven violence within sporting contexts include the Tlatelolco massacre in Mexico City, 10 days before the 1968 Olympics, when police and military forces broke up an anti-government demonstration, killing at least 44 people and wounding hundreds. In Pinochet's Chile and Afghanistan under the Taliban, 
sport stadiums were used as venues for the detention and execution of civilians. Moreover, sports teams have also been at the centre of violent conflicts, most obviously involving armed attacks on the Israeli Olympic team in Munich in 1972, and more recently on the Sri Lankan cricket team in Pakistan and the Togo football team in Angola.

More broadly sport during this period has also been used for the symbolic flexing of militarised, nationalist, masculine muscles. The 1936 'Nazi Olympics' provide the most obvious example, although cold war Olympic boycotts by the USA and USSR are also indicative. Moreover, most major national sporting events during this period came to be established as collective rituals in which the nation's military were on display in some form or other. Additionally, sport came to be seen as one populist medium through which military or 'authoritarian populist' regimes might mobilise the energies and support of the masses.

Thus, throughout this period, sport's association with the military continued to be largely orientated towards the primary functions of armed forces, in regard to the actual exercise or symbolic threat of violence. The roles of ethno-national and ethno-religious ideologies, in conjunction with the modern state, were also more prominent during this phase.

Sport-military-global society 3: sport, development, peace

This period spans the 1990s onwards, and is marked by a growing use of sport as an interventionist tool for promoting peace and development. This does not mean that the main sport-military associations within phases 1 and 2 have disappeared; rather, phase 3 highlights the emergence of a distinctive and expanding use of sport for alternative military purposes. Moreover, it should be emphasised that significant elements of these processes have long been evident in sport. The practice of ekecheiria in Ancient Greece sought to ensure safe passage of athletes and travellers who were heading to the Olympic Games. The notion of the Olympic Truce has subsequently been followed up by the United Nations, which since 1993 has passed resolutions that call for world peace during this mega-event. During the First World War an informal Christmas Truce between German and British forces occurred in 1914. Although exact details are sketchy, part of the mythology surrounding this event points towards rival troops playing football. ${ }^{20}$ More broadly sporting events such as the Olympic Games have long been overlain with ideologies of internationalism and universalism. ${ }^{21}$ 
Our argument here is that such processes provide the important historical backdrop for the subsequent crystallisation and expansion of the SDP sector in the 1990s and onwards. This sector has been marked by the establishment of a wide variety of agencies that promote sport's peace-building functions. At the same time the role of the military has undergone substantial changes over the past two decades. Increasingly international military forces are being deployed as peace-making agencies within post-conflict situations. 'Peace operations' feature 'uniformed personnel', both male and female, that have a 'mandate or programme' to assist peace processes, to observe or assist ceasefires, and to be able to enforce ceasefires, peace processes or UN Security Council decisions aimed at creating a 'stable peace'. ${ }^{22}$ Such practices have clearly become more evident across the world, notably in regard to the use of 'neutral' United Nations troops in the Balkans, Middle East and Africa.

Thus, as the function of the military moves towards establishing a sustainable peace, and winning the 'hearts and minds' of citizens, it makes sense to explore sport's potential contribution to meeting these objectives. Yet the interplay of forces associated with all three phases will vary significantly, according to context. In order to explore these processes, we examine two specific case studies relating to the sport-military nexus, in the Balkans and Liberia respectively. The findings from these case studies point towards ways in which the key elements within these three phases may be played out within other contexts, particularly within the global South, where such conflicts are more readily apparent.

\section{The sport-military nexus: the Balkans and Liberia}

\section{Balkeans}

The ethno-nationalist and ethno-religious enmities within the Balkans are notorious for their lengthy history, spanning many centuries. Here, however, we begin in May 1990, at a football match between Dinamo Zagreb and Belgrade Red Star in the Croatian capital of Zagreb, a fixture which 'gave a premonition of the war that would rage in the area for the next decade'. ${ }^{23}$ The match provoked mass disorder both on and off the football pitch. The post-match riot in the capital, unlike more 'routine' hooliganism at such fixtures, had clear political overtones and was well planned. The whole event and its aftermath revealed intimate connections between sport, ethno-religious politics and impending civil war. 
The Croatian supporters movement, the Bad Blue Boys, and the Serbian equivalent, the Delije, transmogrified from football formations to paramilitary units in the ensuing civil war. ${ }^{24}$ The head of the Delijie club was Zeljko Raznatovic (or Arkan) who formed the Serbian Volunteer Guard, one of the most feared and brutal paramilitary groups during the war. The core of his militia comprised young men drawn from the Delijie fan club. Raznatovic is quoted as having said, 'we are fans. . trained without weapons'. ${ }^{25}$ In the former Yugoslavia supporters who caused trouble had previously been classified as 'anti-social'. Suddenly they became valuable, particularly to those driving the push to war. ${ }^{26}$

Bosnia experienced the most violent and sustained conflict during the Yugoslavian civil war. This conflict ran from 1992 to 1995, and is estimated to have killed 200000 and displaced over two million, roughly half the population. It was a particularly vicious conflict, marked by the targeting of civilians for genocide, mass rape and 'ethnic cleansing'. ${ }^{27}$ At the conflict's end Bosnia was left with three recognised 'constituent peoples' within a federalised political system: Bosniaks (mainly Muslims) who identified most with Bosnia; Bosnian Serbs (mainly located within the Republika Srpska) who identified with Serbia; and Bosnian Croats, who identified particularly with Croatia. $^{28}$

Tensions between the rival communities in Bosnia can be witnessed during international matches. For example, during Bosnia's recent 2-1 victory over Belgium in the 2010 World Cup qualifiers, some Bosniaks were attacked in the Republika Srpska for waving Bosnian flags from cars. During the 2006 World Cup qualifying campaign Serbia played against Bosnia in Sarajevo, where Bosnian fans held up banners stating, 'We have 250000 reasons to hate you', referring to estimated war deaths. During Bosnia-Serbia fixtures the chants of some Bosnian Serb supporters of 'knife, wire, Srebrenica' may be met with the Bosniak response of 'Ubi Srbi' (Kill the Serb).

Thus, the former Yugoslavia highlights acutely the ways in which sport and military relations continue to reflect processes within the first and second historical phases. As in the imperial past, forces involved in the civil war drew substantially upon sport-related social movements in order to fill their military units. As in the second phase, we also find fervent ethno-nationalist and ethno-religious ideologies inflaming the sport-military nexus.

Yet, in turn, the former Yugoslavia has also opened up some possibilities for third phase sportmilitary relations. In Bosnia, for example, both the Union of European Football Associations 
(UEFA) and the Fédération Internationale de Football Association (FIFA) have financed NGOs which employ football to build better relations between the divided communities, particularly among Bosniaks and Serbs. In the post-conflict environment in Bosnia villages of people from the divided communities may be only 30 or 40 kilometres apart, yet social contact across these divisions may be minimal. Thus, football and other sports are used to 'break the ice' between these divided groups, to enable children in particular to encounter and to interact with 'the other' within a familiar, rule-governed and meaningful social framework. ${ }^{29}$

Notably the interventionist techniques of NGOs can vary significantly in philosophy, strategy and tactics. The fieldwork which we have conducted reveals that some NGOs prefer to organise football events that have relatively orthodox structures, wherein separate teams from the rival communities will play against each other in competitive matches. The retention of this principle is viewed as good 'training for life', since it requires participants to accept that other groups may be encountered in all types of social setting, including competitive ones. However, the underlying rule-governed nature of sport requires participants to control and direct their behaviour according to widely recognised conventions - in this case the generalised 'rules' of the game, which include prohibitions on 'violent' types of play. Some adjustments are made to the rules in order to promote gender inclusion, for example by having goals scored by girls 'count double'. Importantly the organisers of these events try to encourage the participating players to referee the games themselves. This requires the participants to draw on their common 'stocks of knowledge' regarding the rules and conventions of football, and is also very much in line with the informal, practical and sociable ethos of 'street football'.

Other NGOs depart from the modern principles of competitive sport, and instead emphasise humanist and integrative values centred on skill, fun and achievement. In this case the relevant NGOs organise sport events which immerse local children in diverse coaching and play sessions. The community divisions are immediately removed at the outset by having all children equipped in the same sports kit. Where the activity sessions involve team play, each group features children from all communities, to enable positive social dynamics to be constructed across communal divides.

Key factors that underpin the long-term success of both types of project are, most importantly, political and military stability within the post-conflict setting; the sustainability of the project, in terms of financial and infrastructural support; and the effective participation of other stakeholders in the peace-making process at local and national levels. In the Bosnian case the 
first two factors have appeared in good shape, given the relative stability of the post-conflict settlement, and the economic backing received by external agencies. More problematically, however, co-ordination with wider peace-making forces can be somewhat uneven. In most settings, given the rather limited scale of these sport NGOs, the fault lies mainly with larger agencies for failing to know about, or to engage with, the sport-based work that is taking place. Significantly there also appears to be a rather limited range of communication between the sport projects and the peacekeeping military forces in the region. This is a weakness that is not exclusive to Bosnia, but is also evident in the post-conflict context, as we also encountered in Liberia.

\section{Liberia}

The West African Liberian state provides a micro-study of the use of sport in the peace-building and reconstruction of war-ravaged societies. Our fieldwork in Liberia during the 1990s and 2000s was undertaken when this nation hosted the world's largest peacekeeping force, comprising more than 15000 soldiers and police under the auspices of the United Nations Mission in Liberia (UNMIL).

In recent times Liberia has been deeply ravaged by two civil wars (1989-96, then 1999-2003), much of which centred on Charles Taylor, leader of a rebel army, who latterly held the Liberian presidency, but who is now being tried for crimes against humanity by the UN Special Court for Sierra Leone. The first, main conflict killed around 200000 Liberians, and was marked by extreme barbarity, including the systematic rape, torture and execution of civilians and combatants. ${ }^{30}$ The use of 'child soldiers' was widespread in both Liberia and neighbouring Sierra Leone, where Taylor is understood to have been one of many rival parties involved in arms and 'blood diamond' trafficking. Child soldiers were socialised into brutal violence, and many acquired drug addictions, leaving government, NGOs and intergovernmental institutions with the very hard task of rehabilitating and re-socialising these children within a post-conflict situation. ${ }^{31}$ During the second conflict Taylor was driven out of Liberia, largely by the LURD military force which was itself guilty of many atrocities. In turn, the UN established a peacekeeping mission in Liberia in 2003, and relative stability has been maintained.

We found little evidence of a significant and meaningful association between military activity and sport practices among combatants in the civil war, save for the wearing of football shirts by some young soldiers, or gory reports of body parts being used in games during breaks in fighting. 
During our post-conflict fieldwork the main elements of the third phase were more evident, wherein sport interventionist strategies sought to promote peace and development among young Liberians. Typical, relatively small-scale initiatives included a week-long 'reconciliation through sport' tournament, which we attended, designed for 16 clubs in the third division of the local football league.

A more expansive event was a youth soccer tournament, entitled 'United Through Sports', which was held at the national stadium, with support from the national government (Ministry of Youth and Sports), the international NGO community (e.g. World Vision), international governments (notably the US Embassy), and the corporate sector (e.g. Nike). The event was organized by UNMIL and CIVPOL (the UN's civilian police force), in collaboration with the Liberian Football Association. The event and location served to crystallise many of the difficulties and problems that sport-based peace-making initiatives encounter in the global South. To begin with, the environment for the event, despite significant recent investment, continued to have material and symbolic problems. The stadium had been built with support from FIFA, as reflected in the graphics and murals on the walls. Yet, as a poignant reminder of recent conflict, the external walls were pockmarked by bullet-holes, while the new stadium floodlights lacked electrical power. More importantly public participation was relatively muted, ironically in part because of the effects of cultural globalisation. A small crowd of around 2000 local people ( $95 \%$ male) attended the event. We were informed later by one football official that crowds for local fixtures had dipped by $40 \%$, as Liberian fans preferred to watch live European matches on television. Indeed, as this event took place, satellite television was broadcasting an English Premier League fixture.

One further complicating factor in regard to peace-making through sport is the condition of the local football system, and in particular the extraordinary influence of George Weah, Liberia's most famous citizen. Weah had an illustrious career as a professional footballer in Europe, playing for leading clubs such as Monaco, Paris Saint-Germain, AC Milan and Chelsea from 1988 to 2001, while also winning the World Footballer of the Year award in 1995. Weah's absence from Liberia had largely helped him to avoid coming into direct contact with military violence during the 1990s and early 2000s, although he had challenged the corrupt siphoning of football revenues, and his house had been ransacked by militias during the Taylor regime. His global celebrity status ensured that many development agencies and charities were keen to establish personal endorsements; thus Weah was recruited by UNESCO as a 'Goodwill 
Ambassador for Sport'. After the second civil war Weah returned to Liberia, to live in a vast mansion in Monrovia, providing employment and financial support for up to 100 local people. As the quintessentially iconic figure in Liberian society, Weah entered politics and stood for the presidency in 2005, but was defeated by Ellen Johnson-Sirleaf, a former World Bank official. ${ }^{32}$ It is anticipated that he will return to contest the presidency at a later date, although the substance of his policies, and the identity of his main allies, remain unclear.

Latterly the UN has introduced an innovative 'Sports for Peace' programme to promote reconciliation and development. In 2007 President Johnson-Sirleaf gave the inaugural kick-off at a weekend tournament in Monrovia, to launch the five-week programme to be held throughout Liberia's 15 counties. ${ }^{33}$ At the opening ceremony the UN's then Special Advisor on Sport for Development and Peace, Mr Adolf Ogi, emphasised sport's function as an essential tool for creating peace, national reconciliation and harmony. Ms Johnson-Sirleaf recalled that, during the nation's 14-year civil war, sporting activities, especially football matches involving the Liberian national team, could bring sudden ceasefires between the warring factions. With support from the International Olympic Committee (IOC), sports goods and equipment to the value of US\$76000 were delivered to the Liberian authorities and UNMIL.

These national events and initiatives must be more than matched by grassroots activities which are sustainable and socially engaged. Only when sports clubs and systems are established at everyday level is it possible for young West Africans to explore, through sport, forms of positive personal and social development. In West Africa, as Richards has demonstrated, football provides a social sphere in which those caught up in conflict-either as victims or as perpetrators-may come into positive mutual contact, and in turn set out on the hazardous path of establishing trust and reconciliation. ${ }^{34}$ In Liberia a strong illustration of this process is demonstrated by the Salesians of Don Bosco, who established the Bosco United Sports Association, a network of clubs (mainly football) which afforded young 'at risk' Liberians a social alternative to criminal, abusive and violent practices. ${ }^{35}$

Missing from Liberia, however, has been the concerted involvement of peacekeeping forces in sporting practices. In most sport-based interventions the peacekeepers take a back seat, rather than put to work their organisational and sporting expertise to assist local citizens. Such an engagement would potentially serve to promote interactive trust between the peacekeepers and those who are being 'kept in peace'. A crucial point to bear in mind here is the everyday social bonds, or forms of 'bridging social capital', that might be forged between individual 
peacekeepers and local people, since many of the latter are drawn from the paramilitary and rebel forces which had been at the centre of Liberia's civil war. ${ }^{36}$ As in Bosnia, Liberia provides an illustration where there is need for a stronger strategy that links the peacekeeping groups into the diverse activities of intergovernmental organisations (such as the UN and its agencies) and the multifarious NGOs (whether these are local, national or international).

One final, important point to be made here is the need for gender relations within the host setting to be fully understood. In many settings peacebuilding officials will have to engage with distinctive, deep-seated cultural values, which may proscribe forms of inter-gender social relations; they will also have to understand the different traumas and tragedies faced by women during recent conflicts, such as the loss of family members, mass rape, and other forms of sexual, physical and emotional abuse. The planning of sport-based interventions will have to take stock of the extent to which cross-gender social interaction is tolerated culturally. In some circumstances, for example, attempts by male soldiers to engage women in sport may be viewed as culturally confrontational or offensive. Some effective methods for overcoming these difficulties include the establishment of separate play areas for women, the adaptation of established sports, or the use of non-invasive team sports to promote greater cross-gender participation.

\section{Peacekeeping forces: the work of CISM}

If we are to explore how peacekeepers may contribute to sport's peace-making role, one of the best organisations to consider is the Conseil International du Sport Militaire (CISM). Founded in 1948 by five West European nations, CISM has since grown into one of the world's largest multidisciplinary organisations, with a current total of 127 national members. ${ }^{37}$ Thus, in terms of multidisciplinary sports, CISM is second only to the IOC in scale. The Military World Games are organised by CISM every four years, most recently at Hyderabad, India in 2007, where 84 nations competed. In 2011 they will take place in Rio de Janeiro.

Historically, as we have seen, the military have tended to view sporting experiences as valuable in providing a sense of preparedness for battle. However, CISM's stated ethos points more towards the 'Sport-global society 3' phase, in stating that military sport is intended to:

Promote physical education and sports activities, provide mutual technical assistance, support less privileged members in the name of friendship and solidarity, contribute towards the balanced and harmonious development of 
military personnel, and contribute to the international effort for universal peace. ${ }^{38}$

Unlike the Olympics, CISM championships are decentralised and each is sponsored by a single country. Thus, it becomes 'economically feasible for even the smallest emerging Asian or African nation to organise a championship every few years' ${ }^{39}$ In 1995 CISM created the Solidarity Commission which backed the 'Race of Hope'-a fund-raising programme aimed at building sport and cultural centres for African war orphans. At the same time CISM carried out 'solidarity missions' in co-operation with organisations such as the IOC, UNESCO, the EU and the World Federation of the Sporting Goods Industry (WFSGI) in more than 20 nations.

CISM represents potentially the best transnational agency if the SDP sector is to extend its activities and supporting institutions by engaging with peacekeepers. There are three main issues underlying this argument. First, we have argued elsewhere that much behind-the-scenes activity within the transnational SDP sector is centred on building networks and partnerships, and supporting knowledge transfer. ${ }^{40}$ Among the many international conferences in recent years which have worked with diverse SDP agencies some recent events have started to engage with military peacekeepers, and with CISM in particular. ${ }^{41}$ This type of deeper engagement would enable the many different institutions within the SDP sector to think more fully about how CISM and other peacekeeping forces may be actively utilised within conflict zones. Second, CISM's sheer scale indicates that, if the SDP sector is to engage with military peacekeepers, this would be the ideal transnational agency to work alongside as part of that objective. Third, the potential contribution of CISM to reshaping the sport-military nexus should not be discounted. In this sense the use of sport by military peacemakers may have deeper functions, in terms of enabling these forces to explore new ways of working with civilian populations through innovative techniques of communication and engagement. In the concluding section, we explore how the SDP sector may move more fully forward in regard to engaging with the military and peacekeeping agencies.

\section{Concluding comments and policy recommendations}

Like all other cultural forms, any sport can be adapted and implemented to suit particular politico-ideological and socio-cultural objectives. Thus we find that, historically, sport has displayed a complex and ambivalent relationship to militarisation and violent conflict. 
In recent times, with the emergence of the SDP sector, sport has been harnessed to play roles in post-conflict peace-building and reconciliation processes. It is worth highlighting the different contributions that sport may make in this regard. Sport participation may 'break the ice' (as in Bosnia) between divided communities, or assist in re-socialising combatants or those traumatised by warfare (as in Liberia). Sport participation also serves to build everyday social capital and networks, and thus contributes to a stronger civil society. The commitment to building sporting activities is dependent on the creation of a safe and secure environment, which is a prerequisite for other post-conflict and reconciliatory processes. Sport appeals particularly to the demographic most responsible for violent conflict-young men-and is thus a highly effective communicative tool for engaging with actual or potential combatants.

However, we need also to be careful in regard to sport's contribution to peace building. Those involved in the peace-building process should realise that ready-made sport cannot be parachuted into a post-conflict context, and be implemented according to a 'global manual'. It is crucial that any sport-based intervention be highly sensitive to the local context and to the issues that underpin the conflict. Specific attention needs to be paid to the nature of gender relations within the local context, in order to identify the appropriate intervention strategies for engaging women as well as men. Local people need to have a strong sense of their decision-making influences and ownership in regard to the sport-based project. Moreover, the sport project needs also to locate itself carefully within the complex network of peace-building institutions and agencies, in order to maximise its contribution.

It is within this developmental environment that we anticipate the greater engagement of peacekeepers within the peace-building work of the SDP sector. Involving peacekeepers in SDP work would help the sector to break new ground, as part of a wider and fuller engagement with a broader range of institutional actors, in order to facilitate peace in diverse circumstances. It would enable the SDP sector to work with a transnational network of tens of thousands of external 'workers', whose stated function is the preservation and promotion of peace, and who have very direct social contact with the most 'at risk' groups, particularly young local males who might otherwise find themselves in violent conflict. As we have argued, CISM constitutes perhaps the best institutional gatekeeper for connecting the SDP sector with on-the-ground peacekeeping forces. This contribution of CISM also helps, in a modest but definite way, in promoting the 'third phase' aspect of the sport-military nexus, with its emphasis on 
development and peace, as opposed to the concerns of the first and second phases with the violent, invasive and repressive aspects of military practice.

It is, of course, essential that the SDP sector's work with peacekeepers be conducted with great contextual sensitivity. In some circumstances, for example, the peace-keepers may be viewed as an invasive force by significant local parties, and thus their contribution to SDP work is highly problematic. Similarly it is important that sport-related interventions be introduced in good faith, and not as a mere medium of 'soft power' that enables external or sectional interests to secure control over populations. Moreover, to succeed, the sport-based activities of peacekeepers need to be located more fully within the network of peace-building NGOs, sport federations, intergovernmental agencies and other interested parties.

All these insights point back to our earlier statement that stronger peacebuilding strategies are required in each location, to encompass and interconnect the aspirations and activities of different institutions and agencies, including the relevant peacekeepers. What is also missing, but more readily remedied, is the relatively limited training which peacekeepers have in regard to sport-based interventions. In providing such training, CISM and the SDP sector more generally would be required to think through, and to plan out, the different roles offered by peacekeepers in regard to sport-based interventions, which in turn are directly intended to help build more secure post-conflict societies.

\section{Acknowledgements}

The authors are indebted to Brigadier General Gianni Gola, Captain Roberto Correia, Major Pedro Gagliardi and Lt-Colonel Suzana Tkava for the time and hospitality afforded them when guests of CISM. Thanks are also due to Jacob Wilmer, who inspired our thinking. Giulianotti's research was financed through a grant from the Nuffield Foundation. Our gratitude is extended to the anonymous reviewers whose constructive comments assisted in the completion of this paper. Sincere thanks are extended to the editors of this edition for the opportunity they provided to publish our research.

\section{Notes}


${ }^{1}$ P Donnelly, 'Sport for development and peace: a public sociology perspective', paper presented at the 'Sport and International Development: Mainstreaming Sport into Developmental Studies' conference, Department of International Development Studies, Dalhousie University, 20-21 May 2010.

${ }^{2}$ See http://www.un.org/sport2005/a_year/facts.pdf, accessed 3 July 2010.

${ }^{3}$ R Giulianotti, 'The sport, development and peace sector: a model of four social policy domains', Journal of Social Policy, 40(4), 2011, in press; and R Giulianotti, 'Sport, peacemaking and conflict resolution: a contextual analysis and modelling of the sport, development and peace sector', Ethnic and Racial Studies, 2011, pp 207-228.

${ }^{4}$ G Armstrong, 'The Lords of Misrule: football and the rights of the child in Liberia, West Africa', Sport in Society, 7(3), 2004, pp 473-502; Armstrong, 'Life, death and the biscuit: football and the embodiment of society in Liberia, West Africa', in G Armstrong \& R Giulianotti (eds), Football in Africa, Basingstoke: Palgrave, 2004, pp 183-209; Armstrong, 'The global footballer and the local warzone: George Weah and transnational networks in Liberia, West Africa', Global Networks, 7(2), 2007, pp 230-247; R Giulianotti, 'Human rights, globalization and sentimental education: the case of sport', Sport in Society, 7(3), 2004, pp 355-369; Giulianotti, 'The sport, development and peace sector'; and Giulianotti, 'Sport, peacemaking and conflict resolution'.

${ }^{5} \mathrm{~S}$ Guldenpfenning, 'Sport in the peace movement: a challenge for social science', International Review for the Sociology of Sport, 20(3), 1985, pp 203-213.

${ }^{6}$ Plato, Republic, ed IA Richards, Cambridge: Cambridge University Press, 1966, pp 59-61.

7 See N Fischer, 'Competitive sport's imitation of war: imaging the completeness of virtue', Journal of the Philosophy of Sport, 29, 2002, pp 16-37.

${ }^{8}$ See N Elias \& E Dunning, Quest for Excitement, Oxford: Blackwell, 1986.

${ }^{9}$ See JA Mangan (ed), Tribal Identities, London: Frank Cass, 1996; M Marqusee, War Minus The Shooting, London: Mandarin, 1997; and F Foer, How Soccer Explains the World, London: Harper Collins, 2005.

${ }^{10}$ See JA Mangan (ed), Shaping the Superman: Fascist Body as Political Icon-Aryan Fascism, London: Frank Cass, 1999; and T Collins, 'English Rugby Union and the First World War', The Historical Journal, 45, 2002, pp 797-817.

${ }^{11}$ Giulianotti, 'Sport, peacemaking and conflict resolution'.

${ }^{12}$ See J Hargreaves, Sport, Power and Culture, Cambridge: Polity, 1986; R Holt, Sport and the British: A Modern History, Oxford: Oxford University Press; and JA Mangan, The Games Ethic and Imperialism, Harmondsworth: Viking, 1986.

${ }^{13}$ JA Mangan, Athleticism in the Victorian and Edwardian Public School, Cambridge: Cambridge University Press, 1981, p 194.

${ }^{14}$ Cf GJ De Groot (ed), Blighty: British Society in the Era of the Great War, London: Longman, 1996.

${ }^{15}$ N Ferguson, Empire: How Britain Made the Modern World, London: Penguin, 2003, p 260.

${ }^{16}$ JA McCarthy, War Games, London: Queen Ann Press, 1978, p 23. For the Russian novelist Maxim Gorky, 'bourgeois sport' had 'a single clear purpose: to make men even more stupid than they are . . In bourgeois states, sport is employed to produce cannon fodder for imperialist wars'. Cited in J Riordan, Sport in Soviet Society, Cambridge: Cambridge University Press, 1977, p 351.

${ }^{17}$ Newsome, cited in De Grool, Blighty.

${ }^{18}$ WJ Baker \& JA Mangan (eds), Sport in Africa: Essays in Social History, London: Africana Publishing Company, 1987; and SWagg \& DL Andrews (eds), East Plays West: Sport and the ColdWar, London: Routledge, 2006.

${ }^{19}$ R Kapuscinski, The Soccer War, New York: Random House, 1995; and S Kuper, Football Against the Enemy, London: Orion, 1995. 
${ }^{20}$ M Brown \& S Seaton, Christmas Truce: Western Front, 1914, London: Pan, 1984.

${ }^{21}$ A Guttmann, The Olympics: A History of the Modern Games, Urbana, IL: University of Illinois Press, 2002, p 28.

${ }^{22}$ AJ Bellamy \& P Williams, Understanding Peacekeeping, Cambridge: Polity, p 18.

${ }^{23}$ AL Sack \& Z Suster, 'Soccer and Croatian nationalism: a prelude to war', Journal of Sport and Social Issues, 24(3), p 310.

${ }^{24} \mathrm{~S}$ Vrcan \& D Lalic, 'From ends to trenches and back: football in the former Yugoslavia', in G Armstrong \& R Giulianotti (eds), Football Cultures and Identities, Basingstoke: Macmillan, 1998.

${ }^{25}$ See T Judah, cited in Sack \& Suster, 'Soccer and Croatian nationalism', p 312.

${ }^{26}$ See I Colovic, The Politics of Symbol in Serbia, London: Hurst, 2002, p 283. In October 1999 the Yugoslav team travelled to Zagreb to play Croatia in a qualifying match for the Euro 2000 Championships. Just as in 1990, when the match ended in riot, this match contained elements of political theatre. Croatian President Franjo Tudjman, paid tribute to Croat war veterans, many of whom had fought in the recent war against Serbs. In an interview, aired in a film documentary, a leader of the Bad Blue Boys commented that Croatia needed a victory to avenge what Yugoslavia had done to his country during the war and to honour the Croatian soldiers who had died. $\mathrm{He}$ alluded to the fact that no Serbians were present and bragged that, if they had been, they would have been greeted by hand grenades and bullets rather than by stones as in the 1990 riot. See Sack \& Suster, 'Soccer and Croatian nationalism', p 318.

${ }^{27}$ M Kaldor, New and Old Wars: Organised Violence in a Global Era, Cambridge: Polity, 1999.

${ }^{28}$ On the complex relationship between Croatian militant fandom and nationalist politics, see $\mathrm{S}$ Vrcan, 'The curious drama of the president of a republic versus a football fan tribe: a symptomatic case in the post-communist transition in Croatia', International Review for the Sociology of Sport, 37(1), 2002, pp 59-77.

${ }^{29}$ PK Gasser \& A Levinsen, 'Breaking post-war ice: open fun football schools in Bosnia and Herzegovina', Sport in Society, 7(2), 2004, pp 457-472; and D Sterchele, Un calcio alla guerra? Pratiche rituali, appartenenze collettive e conflitto politico in Bosnia Erzegovina, Milan: Guerini, 2008.

${ }^{30}$ See A Adebajo, Liberia's Civil War, Boulder, CO: Lynne Riener, 2002; and M Huband, The Liberian Civil War, London: Routledge, 1998.

${ }^{31}$ See A Sesay (ed), Civil War, Child Soldiers, and Post-Conflict Peace-Building in West Africa, Lagos: College Press Publishers, 2003.

32 See G Armstrong, 'The global footballer and the local war zone: George Weah and transnational networks in Liberia, West Africa', Global Networks, 7(2), 2004, pp 230-247.

${ }^{33}$ See http://www.un.org/apps/news/story.asp?NewsID $1 / 421755 \& \mathrm{Cr}^{1 / 4} \& \mathrm{Cr} 11 / 4$, accessed 3 July 2010.

${ }^{34} \mathrm{P}$ Richards, 'Soccer and violence in war-torn Africa: soccer and social rehabilitation in Sierra Leone', in G Armstrong \& R Giulianotti (eds), Entering the Field: New Perspectives in World Football, Oxford: Berg, 2007.

${ }^{35}$ Armstrong, 'The Lords of Misrule'.

${ }^{36} \mathrm{R}$ Putnam, Bowling Alone, New York: Simon and Schuster, 2000.

${ }^{37}$ A Zechner \& R Van Meerbeek, CISM: Sixty Years of Friendship through Sport 1948-2008, Rome: Centro Tipografica Fiamme Gialle, 2008.

${ }^{38}$ See http://www.cism-milsport.org/eng/a_cism/a2_goals.html, accessed 3 July 2010.

${ }^{39}$ WS McNamara, 'The international military sports council (CISM): its contribution to the Olympic Games and to world sports', Journal of Physical Education, 11, 1975, pp 8-13.

${ }^{40}$ See Giulianotti, 'The sport, development and peace sector'. 
${ }^{41}$ For example, the 2009 Peace and Sport International Forum, hosted in Monaco, featured a plenary session on the role of the military, and included speakers from CISM, the UN in West Africa, and an NGO based particularly in the former Yugoslavia. 